\title{
Sources of Food Affect Dietary Adequacy of Inuit Women of Childbearing Age in Arctic Canada
}

\author{
Sara E. Schaefer', Eva Erber', Janel P. Trzaskos', Cindy Roache³, \\ Geraldine Osborne ${ }^{2}$, and Sangita Sharma ${ }^{3}$ \\ 'Nutrition Research Institute, University of North Carolina at Chapel Hill, Kannapolis, NC 2808I, USA, \\ ${ }^{2}$ Department of Health and Social Services, Government of Nunavut, Nunavut, Canada, and ${ }^{3}$ Department of Medicine, \\ University of Alberta, Edmonton, Canada
}

\begin{abstract}
Dietary transition in the Arctic is associated with decreased quality of diet, which is of particular concern for women of childbearing age due to the potential impact of maternal nutrition status on the next generation. The study assessed dietary intake and adequacy among Inuit women of childbearing age living in three communities in Nunavut, Canada. A culturally-appropriate quantitative food-frequency questionnaire was administered to 106 Inuit women aged 19-44 years. Sources of key foods, energy and nutrient intakes were determined; dietary adequacy was determined by comparing nutrient intakes with recommendations. The prevalence of overweight/obesity was $>70 \%$, and many consumed inadequate dietary fibre, folate, calcium, potassium, magnesium, and vitamin A, D, E, and K. Non-nutrient-dense foods were primary sources of fat, carbohydrate and sugar intakes and contributed $>30 \%$ of energy. Traditional foods accounted for $21 \%$ of energy and $>50 \%$ of protein and iron intakes. Strategies to improve weight status and nutrient intake are needed among Inuit women in this important life stage.
\end{abstract}

Key words: Arctic; Childbearing age; Cross-sectional studies; Diet; Dietary adequacy; Food consumption; Inuit; Maternal nutrition; Nutritional status; Canada

\section{INTRODUCTION}

Similar to many aboriginal populations worldwide, Inuit women of northern Canada have been undergoing a nutrition transition (1-4). Traditionally, these populations consumed a subsistence diet consisting of hunted and gathered foods, i.e. sea and land mammals, fish, shellfish, birds, and plants. However, within the last 50 years, consumption of imported foods high in fat and sugar and of relatively low nutritional quality has become common (5-11). Although the health benefits of the tradi-

Corresponding and reprint requests should be addressed to:

Dr. Sangita Sharma

Endowed Chair in Aboriginal Health

Professor of Aboriginal and Global Health

Research

Department of Medicine

University of Alberta

1-126 Li Ka Shing Centre for Health Research

Innovation

Edmonton AB T6G 2EI

Canada

Email: sangitag@ualberta.ca

Fax: 780 248-1611 tional diet are not well-understood, it has been recognized as nutrient-rich and protective against various chronic diseases (12-14). Studies of various aboriginal Arctic populations have shown that the recent dietary shift has resulted in decreased quality of diet characterized by excessive macronutrient intake (carbohydrate and fat) and insufficient vitamin and mineral intakes (15-19).

In Nunavut, an Inuit self-governed territory of northern Canada, the prevalence of obesity has increased approximately $88 \%$ more rapidly than the Canadian national average in the last 10 years. According to the Public Health Agency of Canada, approximately $58 \%$ of the Nunavut population was classified as overweight or obese (20). A recent study in three remote Nunavut communities found that $72 \%$ of Inuit adults were overweight or obese (21) and that nutrient-poor foods high in fat and sugar were prominent sources of dietary intake $(11,22,23)$. Further, low intakes of many important nutrients, such as dietary fibre, calcium, folate, and vitamin $\mathrm{A}, \mathrm{D}$, and $\mathrm{E}$, were prevalent (22).

Poor nutrition and related conditions, such as obesity, can threaten the quality of life for all popula- 
tion groups but they are of particular concern for women of childbearing age due to increased risks to reproductive health. Obesity is associated with reduced fertility, and both obesity and diabetes are associated with an increased risk of pregnancyrelated complications that can harm the mother and the offspring (24-34). In addition to the reproductive risks associated with these symptoms of overnutrition, it is well-established that certain micronutrient deficiencies also carry risks for reproductive outcomes. For example, folate deficiency in the first three weeks of pregnancy is a leading cause of infant neural tube defects, and vitamin A deficiency has been suggested to be associated with congenital heart malformations (35-38). Both maternal obesity and micronutrient deficiency are predictors of the nutrition status of an offspring and development of chronic disease in adulthood (39-41).

Data are lacking on how the nutrition transition has specifically affected the diet of women of childbearing age in Nunavut and the potential implications on reproductive health. However, results of a study of Inuit in Arctic Quebec and Baffin Island revealed that birth defects were higher than in the general population, and vitamin A and folate deficiencies were cited as possible contributors to these high rates (29). Due to the potential impacts of poor maternal nutrition on pregnancy outcomes and the health of future generations, specific examination of the current diet of women of childbearing age is warranted in this region of transitioning diet. The objectives of the present study were to examine nutrient intake, dietary adequacy, and sources of main foods contributing to energy and selected nutrient intakes among Inuit women of childbearing age in Nunavut. Such data are necessary to inform the development of an intervention programme to improve dietary adequacy in this high-risk population.

\section{MATERIALS AND METHODS}

\section{Setting}

This cross-sectional study was conducted among three remote communities in the Kitikmeot region (Fig.) of Nunavut, the easternmost of three territories in Arctic Canada. Of a population of approximately 30,000, $25 \%$ self-identify as Inuit. Inuktitut and Inuinnaqtun are the local languages. With a median age of 23 years, Nunavut has the youngest population of any province or territory in Canada (42).

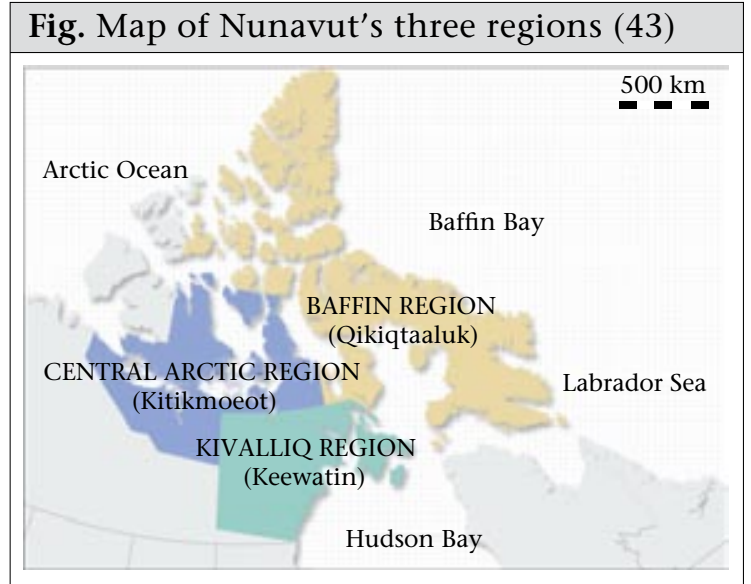

The three participating communities were identified by the Government of Nunavut that represented varying levels of the Inuit population and socioeconomic status. Community populations have been previously described (44) but, in brief, range from 800 to 1,500 people, $80 \%-90 \%$ of whom selfidentify as Inuit. Their median age ranges from 20 to 26 years and employment from $40 \%$ to $60 \%$ (42). One community is a regional centre with a larger non-aboriginal population and greater engagement in the wage economy than the other two. Like many Nunavut communities, each has two food stores that obtain food primarily through shipments from the south via airplane year-round and also via barge/sealift once per year when the ice melts. Because of high cost of transportation and storage, prices of imported foods tend to be elevated compared to prices in southern Canada (45). Food is also obtained, to varying degrees, by traditional means, e.g. hunting and fishing.

\section{Collection of data}

Data were collected as part of a larger study to assess the adequacy of diet among adult Inuit living in the Nunavut communities, and the study protocol has been previously described (44). Briefly, participants were recruited through random selection using upto-date community housing maps provided by the local government. This method ensured sampling from areas with varied proximities to food stores and land resources. One resident per household was recruited, excluding residents aged less than 19 years (children) and pregnant/lactating women due to their different nutritional requirements and possible changes in dietary habits. Response rates in the three communities ranged from $69 \%$ to 93\%. The present study reports data from women of childbearing age (19-44 years) included in the assessment. 
Dietary data were collected during June-October 2008 using an interviewer-administered, culturally-appropriate quantitative food-frequency questionnaire (QFFQ) developed specifically for Inuit in Nunavut (23). The QFFQ was designed using single 24-hour recalls $(n=87)$ to capture all foods/beverages typically consumed, including traditional foods not available in stores and those available seasonally. The QFFQ included 150 food items consumed throughout the year (12 breads and cereals; 65 meat, fish, and poultry; 12 dairy; one non-dairy creamer product; 13 fruits; 19 vegetables; 14 desserts and snacks; nine beverages; two sugar and sweetener products; three alcoholic drinks), 39 of which were traditional foods. The QFFQ has been previously validated using 24-hour recalls collected in the same population, and the two methods showed relative agreement of $83 \%$ for energy, 94\% for sugar, $81 \%$ for macronutrients, and $84 \%$ for micronutrients, indicating that the QFFQ was a valid tool to assess dietary adequacy in this population (46). A population-specific food-composition database was developed using data from the Canadian food-composition tables within NutriBase, Clinical Nutrition Manager (version 7.17) (CyberSoft Inc., Phoenix, AZ), supplemented with data from the Canadian nutrient file.

Heights and weights of the participants were measured in duplicate and recorded on an additional anthropometry form. Heights were recorded to the nearest centimetre using a stadiometer, and weights were recorded to the nearest $1 / 10$ of a kg using a digital scale. Before measurement, the participants were asked to remove shoes and heavy outer clothing, such as jackets. Weight was adjusted for clothing: one $\mathrm{kg}$ for light clothing, $1.5 \mathrm{~kg}$ for medium-weight clothing, and two kg for heavy clothing. If the participant declined to be measured, self-reported measurements were recorded. Two percent of the participants refused to have their heights and weights measured and self-reported the values instead.

Data were collected by community staff trained by the Principal Investigator in the administration and anthropometric measurements of the QFFQ. For participants whose primary language was not English, either an interviewer fluent in the local language conducted the survey or a local interpreter was used.

\section{Analysis of data}

Data were analyzed using the SAS statistical software (version 9.1) (SAS Institute, Inc., Cary, NC). The mean, standard deviation (SD), and median daily energy and selected nutrient intakes were calculated from food intakes (excluding supplements which were taken by $12 \%$ of the population). Participants who reported extreme energy intake $(<2,092$ $\mathrm{kJ}$ (500 kcal) or $>29,288 \mathrm{~kJ}(7,000 \mathrm{kcal}) ; \mathrm{n}=3)$ were excluded from the analysis. Dietary adequacy was determined using the estimated average requirements (EAR) for women per dietary reference intake (DRI) age-groups (19-30 years and 31-50 years) (47). If the EAR was not available, as for dietary fibre, vitamin $\mathrm{D}$, vitamin $\mathrm{K}$, pantothenic acid, potassium, sodium, and calcium, the adequate intake (AI) was used instead. The contribution of key food items to energy, macronutrients, sugar, fibre, calcium, iron, folate, and vitamin $\mathrm{D}$ intake was also determined.

\section{Ethical aspects}

The approval of the Institutional Review Board was obtained from the Committee on Human Studies at the University of Hawaii and the Office of Human Research Ethics at the University of North Carolina at Chapel Hill. The Nunavut Research Institute licensed this study. The participants were remunerated for their time with C\$25 gift cards for local stores. A signed consent form (available in English and the local languages) was obtained from each study participant

\section{RESULTS}

The participants included 106 women with a mean \pm standard deviation (SD) age of $34.1 \pm 6.6$ years and a mean body mass index (BMI) of $29.7 \pm 7.9 \mathrm{~kg} /$ $\mathrm{m}^{2}$ (Table 1).

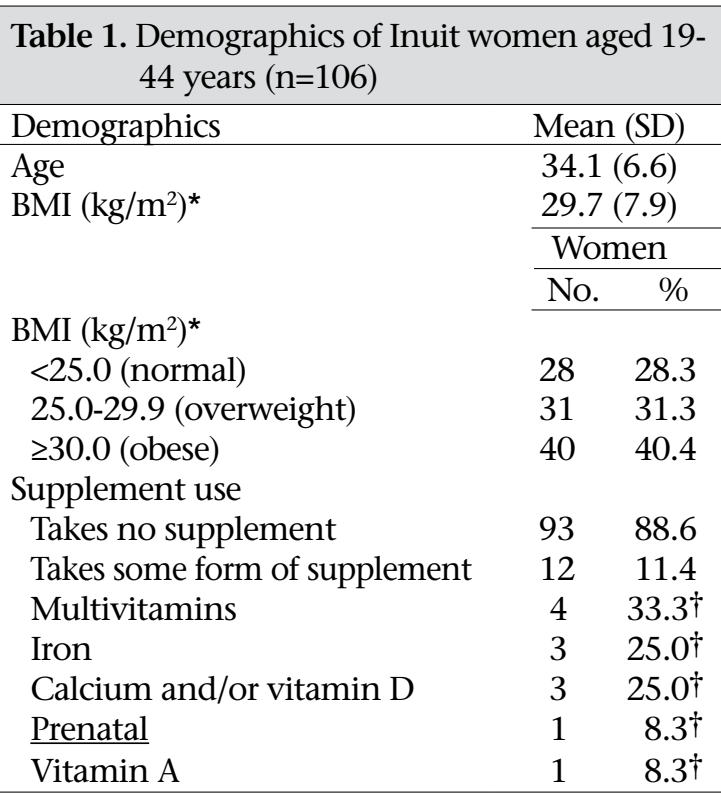

*BMI data not available for six participants; $†$ Of the 12 individuals who reported supplement use; $\mathrm{BMI}=$ Body mass index; $\mathrm{SD}=$ Standard deviation 
Almost $72 \%$ of the participants were overweight or obese according to the World Health Organization (WHO) classifications (48). Only $11.4 \%$ of the women reported taking a micronutrient supplement. Table 2 presents the mean, SD, and median energy and selected nutrient intakes, along with available nutrient DRIs for reference purposes. The mean daily energy intake of the study population was $13,188 \mathrm{~kJ}(3,152 \mathrm{kcal})$, which exceeded the minimum recommended energy intake of 7,531 kJ $(1,800 \mathrm{kcal})(48)$ while the mean dietary fibre $(15$ $\mathrm{g})$, potassium $(4 \mathrm{~g})$, vitamin $\mathrm{D}(5 \mu \mathrm{g})$ and vitamin $\mathrm{E}$ (4 mg) fell below the recommended intakes.

Table 3 shows that when intakes of selected nutrients were compared with their corresponding EARs, most (99\%) women fell below the recommended level for vitamin E. More than 50\% were below the EAR for potassium, $>25 \%$ for folate, and $>15 \%$ for magnesium and vitamin A. More than $90 \%$ of the women consumed dietary fibre below the AI while $>50 \%$ were below the AI for vitamin $\mathrm{D}$ and potassium. More than one-third of the women were below the AI for calcium and vitamin $\mathrm{K}$. Iron, niacin, riboflavin, thiamine, pantothenic acid, vitamin $\mathrm{C}$, vitamin B-12, vitamin B-6, selenium, sodium, and zinc were consumed below the recommended levels by less than $15 \%$ of the women (data not shown).

The top 10 food-groups contributing to energy, macronutrients, sugar and fibre intakes (Table 4), and selected micronutrient intakes are also presented in Table 5. Foods classified as non-nutrient-dense (store-bought foods, particularly foods of high-energy density that are micronutrient poor) contributed the most energy (31\%), fat (22\%), carbohydrate $(51 \%)$ and sugar (76\%) intakes. Such foods, i.e. soft drinks, potato chips, cookies, and non-dairy coffee whitener, are those with high in fat/energy and/or relatively low-nutrient content and are not traditional foods, or classified in other food-groups, such as fruits/vegetables or grains (23). Traditional land foods, i.e. meat, organs, and fat from caribou, polar bear and musk ox, and sea foods, i.e. seal, muktuk (whale skin and fat), and locally-caught fish, accounted for $21 \%$ of energy intake and more than $50 \%$ of protein and iron intakes. White bread was the largest contributor to folate intake (31\%) and was a significant contributor to calcium intake (24\%) as well. However, dairy foods accounted for the greatest proportion (31\%) of calcium intake.

\section{DISCUSSION}

This is the first study that has examined dietary intake of Inuit women of childbearing age in Nuna- vut, and the results highlight various concerns regarding the diet of this population. Overweight and obesity were highly prevalent, and a number of nutrients, including dietary fibre, potassium, vitamin $\mathrm{D}$ and $\mathrm{E}$, were consumed by more than half of the women below levels deemed to be adequate. Folate, calcium, magnesium, and vitamin $\mathrm{A}$ and $\mathrm{K}$ were also inadequately consumed among many women but to a lesser extent (16-46\%).

A woman's pre-conception nutritional intake is a predictor for poor nutrition during pregnancy (49), which can have lasting effects on the health of the offspring. The foetal programming hypothesis proposes that environmental stimuli during intrauterine development may cause epigenetic alterations that permanently alter the functioning of the organism $(50,51)$, and the intrauterine environment is associated with maternal diet and nutrient supply (52). Epidemiological studies provide evidence that maternal undernutrition and conditions relating to overnutrition, i.e. obesity and diabetes, are associated with an offspring's increased risk of developing chronic disease in adulthood $(53,54)$.

There is also evidence that micronutrient deficiencies, which may be caused by insufficient and/or inappropriate dietary intake, can influence pregnancy and also metabolism of the offspring. For example, vitamin $D$ status during pregnancy has been shown to affect preterm delivery, gestational diabetes, and also intrauterine skeletal mineralization (55-57). Vitamin D inadequacy as seen in the present study population highlights an area of concern for Inuit women, especially since adequate vitamin $\mathrm{D}$ from food sources is crucial for inhabitants of the northern regions who have very limited sunlight exposure, particularly during winter months (58).

Some intrauterine micronutrient deficiencies may lead to severe developmental abnormalities or congenital malformations, which have been documented as higher among aboriginal populations compared to non-aboriginal populations in Canada $(29,59)$. For example, the folate status of a woman at conception may influence the development of neural tube defects (NTDs) (36). To increase folate intake among women of childbearing age, folic acid fortification of wheat has effectively reduced the incidence of NTDs in Canada by approximately $50 \%$ (60). In the present study, white bread (which included fortified products) was the food source accounting for the largest portion of folate intake. Despite this, the high prevalence of folate inadequacy among the study population may signify a need for further efforts to improve folate intake among Inuit 


\begin{tabular}{|c|c|c|c|c|}
\hline Nutrient & Mean & $\mathrm{SD}$ & Median & $\mathrm{DRI}^{* \dagger}$ \\
\hline Energy $(\mathrm{kJ})^{\dagger+\dagger}$ & 13,188 & 5,151 & 12,609 & $7,531^{\ddagger}$ \\
\hline Carbohydrate (g) & 381.7 & 172.2 & 361.4 & NA \\
\hline Sugar (g) & 195.2 & 126.7 & 176.0 & $<25 \%$ of energy \\
\hline Fat $(g)$ & 98.0 & 38.7 & 93.2 & NA \\
\hline Monounsaturated fat (g) & 33.3 & 13.6 & 30.8 & NA \\
\hline Polyunsaturated fat (g) & 14.7 & 6.0 & 14.3 & NA \\
\hline Omega-3 (g) & 1.7 & 1.4 & 1.2 & NA \\
\hline Omega-6 (g) & 10.9 & 4.6 & 10.8 & NA \\
\hline Cholesterol (mg) & 510.9 & 378.1 & 447.0 & As low as possible \\
\hline Protein $(\mathrm{g})$ & 176.2 & 103.3 & 154.0 & NA \\
\hline$\%$ of energy from $\mathrm{CHO}$ & 48.5 & 9.2 & 48.3 & $45-65^{\text {I }}$ \\
\hline$\%$ of energy from fat & 28.3 & 5.1 & 28.5 & $20-35^{\text {I }}$ \\
\hline$\%$ of energy from protein & 21.8 & 7.3 & 21.4 & $10-35^{\text {I }}$ \\
\hline Fibre (g) & 15.2 & 6.8 & 14.1 & $25^{\S}$ \\
\hline Calcium (mg) & $1,261.6$ & 627.3 & $1,143.5$ & $800^{\S}$ \\
\hline Folate $^{\star \star}(\mu \mathrm{g})$ & 418.2 & 182.6 & 398.6 & $320^{\dagger \dagger}$ \\
\hline Iron (mg) & 30.8 & 18.7 & 26.9 & $8.1^{\dagger \dagger}$ \\
\hline Magnesium (mg) & 401.1 & 164.5 & 378.0 & $265 \dagger$ \\
\hline Niacin (mg) & 37.4 & 19.0 & 32.6 & $14^{\dagger \dagger}$ \\
\hline Pantothenic acid (mg) & 10.7 & 6.2 & 9.5 & $5^{\S}$ \\
\hline Potassium (g) & 4.4 & 1.8 & 4.1 & $4.7 \S$ \\
\hline Riboflavin (mg) & 4.3 & 2.2 & 3.9 & $0.9^{\dagger \dagger}$ \\
\hline Saturated fat (g) & 34.9 & 13.9 & 33.5 & $<10 \%$ of energy \\
\hline Selenium $(\mu g)$ & 183.3 & 222.1 & 143.3 & $45^{\dagger \dagger}$ \\
\hline Sodium (g) & 4.3 & 2.0 & 3.9 & $1.5^{\S}$ \\
\hline Thiamine (mg) & 2.4 & 1.1 & 2.2 & $0.9 \dagger$ \\
\hline Vitamin $\mathrm{A}\left(\mathrm{RAE}^{\mathrm{III}}\right)(\mu \mathrm{g})$ & $1,016.4$ & 859.8 & 808.7 & $500^{\dagger \dagger}$ \\
\hline Vitamin B-12 $(\mu \mathrm{g})$ & 16.9 & 15.3 & 12.9 & $2.0^{\dagger \dagger}$ \\
\hline Vitamin B-6 (mg) & 2.2 & 1.0 & 2.0 & $1.1^{\dagger \dagger}$ \\
\hline Vitamin C (mg) & 208.3 & 132.8 & 182.3 & $60^{\dagger \dagger}$ \\
\hline Vitamin D $(\mu g))^{\S \S}$ & 5.2 & 5.0 & 3.7 & $10^{\S}$ \\
\hline Vitamin E (mg) & 4.3 & 2.2 & 4.0 & $12^{\dagger \dagger}$ \\
\hline Vitamin K $(\mu g)$ & 129.5 & 116.3 & 95.2 & $90^{\S}$ \\
\hline Zinc (mg) & 22.6 & 14.6 & 19.9 & $6.8^{\dagger \dagger}$ \\
\hline
\end{tabular}

${ }^{*}$ The DRIs are presented in this table as a reference, using adequate intake, estimated average requirement for women aged 19-50 years. Acceptable macronutrient distribution ranges, and recommendation on saturated fat intake by Joint WHO/FAO (Institute of Medicine of the National Academies, 2005 and Joint WHO/FAO Expert Consultation, 2003); †Value for ages 31-50 years chosen as population studied had a higher percentage of women in this age-category; $\$$ Estimated amount of energy needed to maintain energy balance for women aged 31-50 years at the level of very low physical activity-sedentary

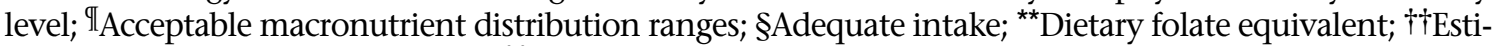
mated average requirement (EAR); ; retinol activity equivalents; $\$ \S$ As cholecalciferol. In the absence of adequate exposure to sunlight; ${ }^{* * *}$ As alpha-tocopherol; ${ }^{\dagger \dagger} 1 \mathrm{~kJ}=0.24 \mathrm{kcal}$; $\mathrm{CHO}=$ Carbohydrate; $\mathrm{DRI}=$ Dietary reference intake; $\mathrm{FAO}=\mathrm{Food}$ and Agriculture Organizations; NA=Not applicable; $\mathrm{RAE}=$ Retinol activity equivalent; $\mathrm{SD}=\mathrm{Standard}$ deviation; WHO=World Health Organization 


\begin{tabular}{|c|c|c|}
\hline \multicolumn{3}{|c|}{$\begin{array}{l}\text { Table 3. Percentage of Inuit women aged 19-44 } \\
\text { years }(n=106) \text { below DRI柿 }\end{array}$} \\
\hline Nutrient & $\begin{array}{c}\text { \% of } \\
\text { women } \\
\text { below DRI }\end{array}$ & DRI \\
\hline Calcium (mg) & 35.8 & $1000^{*}$ \\
\hline Dietary fibre (g) & 90.6 & $25^{*}$ \\
\hline Total folate $\dagger(\mu g)$ & 28.3 & $320^{\ddagger}$ \\
\hline Magnesium (mg) & 17.0 & $255 / 265^{\ddagger}, \mathbb{I}$ \\
\hline Potassium (g) & 62.3 & $4.7^{\star}$ \\
\hline Vitamin $\mathrm{A}\left(\mathrm{RAE}^{\S}\right)(\mu \mathrm{g})$ & 16.0 & $500^{\ddagger}$ \\
\hline $\operatorname{Vitamin} D^{* \star}(\mu g)$ & 60.3 & $200^{*}$ \\
\hline Vitamin $\mathrm{E}^{\dagger \dagger}(\mathrm{mg})$ & 99.1 & $12^{\ddagger}$ \\
\hline Vitamin K $(\mu \mathrm{g})$ & 46.2 & $90^{*}$ \\
\hline \multicolumn{3}{|c|}{ 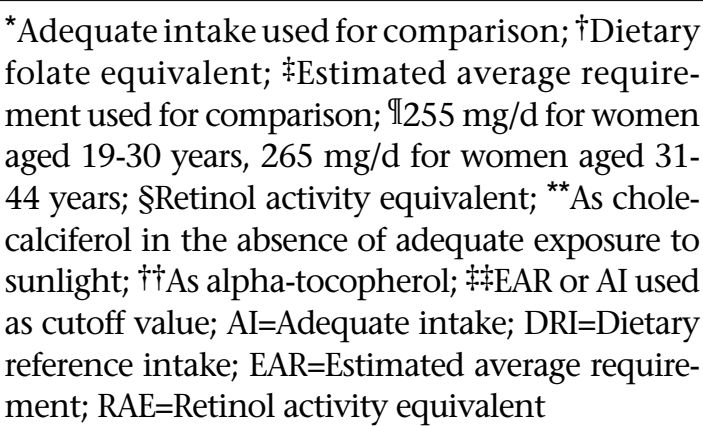 } \\
\hline
\end{tabular}

women of childbearing age via foods rich in folate, supplementation and/or increased consumption of fortified foods. In Canada, NTDs also remain a risk among obese women, even subsequent to folic acid fortification of wheat flour (35), which may be of consequence in the Inuit population given the high rates of obesity.

In the present study, inadequacy of vitamin A was moderately prevalent (16\%) and lower than observed in a study (20). The latter study found that $60 \%$ of Inuit women in Nunavut aged 19-50 years had inadequate intake of vitamin A. Other studies have measured suboptimal vitamin A status in pregnant women and neonates in northern Canada $(61,62)$. Thus, this topic warrants further investigation, particularly regarding possible seasonal variation in intake because of the possible role of vitamin A deficiency in infant congenital heart malformations (38).

The study women consumed excessive energy $(5,657 \mathrm{~kJ}$ or $1,352 \mathrm{kcal}$ higher than the minimum recommendation), which is likely associated with the high prevalence of overweight and obesity. Rates of obesity observed in this population compare with those previously observed in First Nation women (40.4\% and $48.1 \%)$, which suggest that these patterns affect various Aboriginal populations in Canada (63). It is widely accepted that obesity is linked to the development of diabetes and cardiovascular diseases (64). Obesity and diabetes can also increase the risk of poor pregnancy outcomes (25-34) and may also predict an offspring's risk of development of chronic diseases later in life (39-41). In Canada, the financial burden of chronic diseases is significant, and the healthcare system is continuously challenged by the cost of service-delivery to remote communities. Investing in chronic disease-prevention programmes in these communities is essential to adequately manage healthcare costs and to maintain a high quality of life for northern populations. Since the health of women of childbearing age has a direct impact on the health of future generations, efforts that target this population group are of utmost importance.

The study women widely consumed store-bought foods, findings that further evidence the nutrition transition underway in Inuit populations $(4,6,7)$. Non-nutrient-dense, store-bought foods were main contributors to energy, fat, carbohydrate and sugar intakes. Consumption of nutrient-rich fruits and vegetables was very low, contributing to less than $5 \%$ of energy intake. White bread was a notable contributor to folate, iron, and calcium-a benefit of wheat flour fortification. However, this high glycaemic food may cause fluctuations in blood glucose and insulin levels which over time are associated with gain in weight and increased risk of heart disease and diabetes (65). Traditional foods accounted for only $21 \%$ of energy intake but more than $50 \%$ of protein and iron intakes, highlighting the importance of these foods in quality of diet. Further, traditional foods are often good sources of vitamin $\mathrm{A}$ and $\mathrm{D}$, which as mentioned previously, are important in ensuring positive reproductive outcomes.

These findings suggest that, to reduce energy and increase micronutrient intake among Inuit women of childbearing age, efforts targeting the replacement of non-nutrient-dense foods in the diet with traditional foods, fruits, vegetables, and whole grains are needed. Maternal diet may have life-long consequences on an offspring's health and susceptibility to chronic diseases in adulthood. Thus, investing in the promotion of Inuit women's health and nutrition can be expected to have sustained benefits on the health of this population.

\section{Limitations}

Since the study was conducted in only three Inuit communities of Nunavut, the results may not be generalizable to all Inuit communities. Also, the FFQs are generally considered less than optimal 


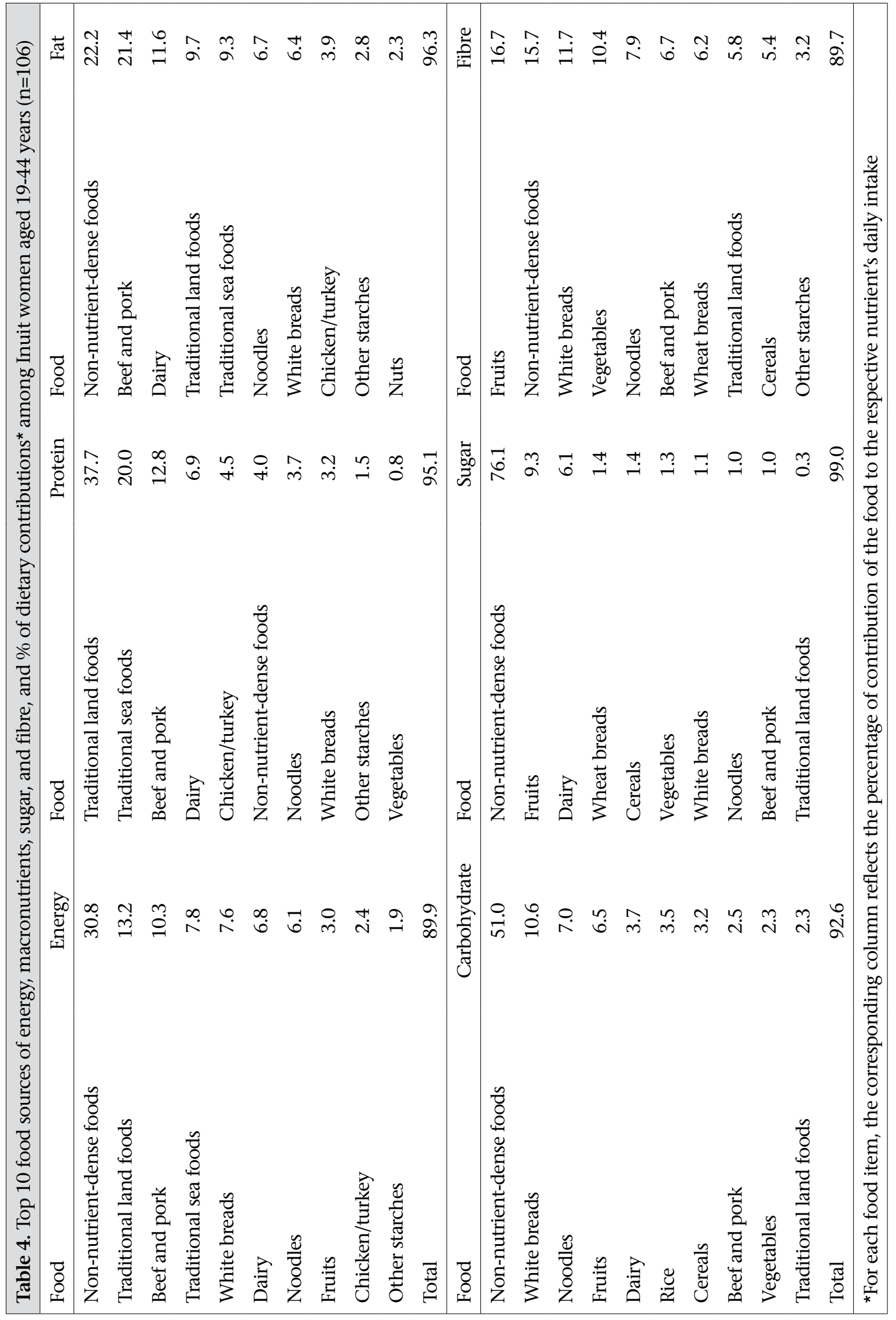




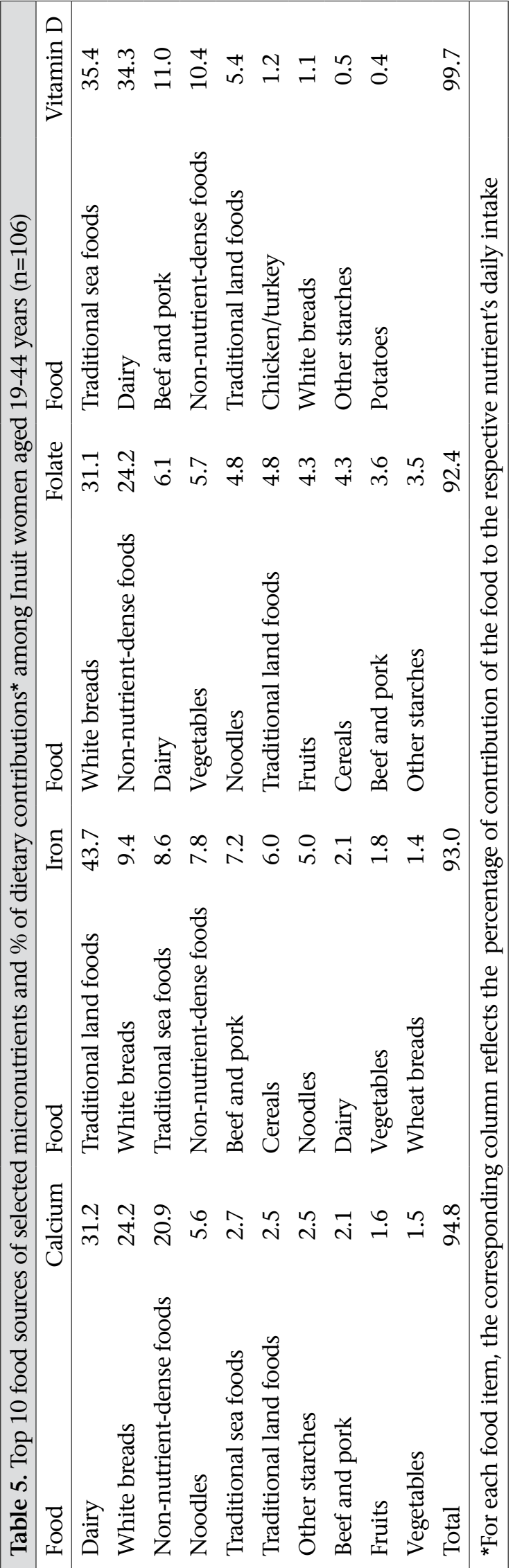

to use to estimate the quantitative parameters of a usual dietary intake of population. However, the QFFQ used in the present study showed high agreement with the repeated 24-hour recall method, and the estimates of the study population's intakes were, thus, considered reasonable and appropriate for determining the dietary adequacy. Further, the QFFQ was developed for the unique Inuit population and contained a culturally-specific food list that captured most foods consumed in these communities. Benefits of using the QFFQ include that it will be a useful tool to monitor how the nutrition transition affects this population and will also allow for evaluating the effects of an intervention to improve dietary intake.

\section{Conclusions}

The Inuit women of childbearing age in Nunavut, Canada, exhibited excessive energy intake, high BMI, and low intakes of several essential nutrients, all of which can impact reproductive outcomes and the health of the offspring. High consumption of non-nutrient-dense foods likely contributed to the poor quality of diet. Education and behaviourchange strategies that promote good nutrition and prevent gain in weight are needed in this vulnerable population sub-group.

\section{ACKNOWLEDGEMENTS}

The project was supported by American Diabetes Association Clinical Research award (no. 1-08-CR57), the Government of the Northwest Territories Department of Health and Social Services, Health Canada, the Public Health Agency of Canada, and the Canadian Public Health Association. The authors thank their community staff for their great support and work on this project. They also thank the communities for their enthusiastic participation.

\section{REFERENCES}

1. Popkin B. Global nutrition dynamics: the world is shifting rapidly toward a diet linked with noncommunicable diseases. Am J Clin Nutr 2006;84:289-98.

2. Condon RG, Collings P, Wenzel G. The best part of life: subsistence hunting, ethnicity, and economic adaptation among young adult Inuit males. Arctic 1995;48:31-46.

3. Bjerregaard P, Young TK, Dewailly E, Ebbesson SO. Indigenous health in the Arctic: an overview of the circumpolar Inuit population. Scand J Public Health 2004;32:390-5.

4. Kuhnlein HV, Receveur O, Soueida R, Egeland GM. Arctic indigenous peoples experience the nutrition 
transition with changing dietary patterns and obesity. J Nutr 2004;134:1447-53.

5. Ebbesson SO, Adler AI, Risica PM, Ebbesson LO, Yeh JL, Go OT et al. Cardiovascular disease and risk factors in three Alaskan Eskimo populations: the Alaska-Siberia Project. Int J Circumpolar Health 2005;64;36586.

6. Batal M, Gray-Donald K, Kuhnlein HV, Receveur O. Estimation of traditional food intake in indigenous communities in Denendeh and the Yukon. Int J Circumpolar Health 2005;64:46-54.

7. Blanchet C, Dewailly E, Ayotte P, Bruneau S, Receveur $\mathrm{O}$, Holub BJ. Contribution of selected traditional and market foods to the diet of Nunavik Inuit women. Can J Diet Pract Res 2000;61:50-9.

8. Wein EE. Evaluating food use by Canadian aboriginal peoples. Can J Physiol Pharmacol 1995;73:759-64.

9. Wein EE, Freeman MMR, Makus JC. Use of and preference for traditional foods among the Belcher Island Inuit. Arctic 1996;49:256-64.

10. Duhaime G, Chabot M, Gaudreault M. Food consumption patterns and socioeconomic factors among the Inuit of Nunavik. Ecol Food Nutr 2002;41:91-118.

11. Hopping BN, Erber E, Mead E, Sheehy T, Roache C, Sharma S. Socioeconomic indicators and frequency of traditional food, junk food, and fruit and vegetable consumption amongst Inuit adults in the Canadian Arctic. J Hum Nutr Diet 2010;23:51-8.

12. Adler AI, Boyko EJ, Schraer CD, Murphy NJ. Lower prevalence of impaired glucose tolerance and diabetes associated with daily seal oil or salmon consumption of Alaska Natives. Diabetes Care 1994;17:1498501.

13. Dewailly E, Blanchet C, Lemieux S, Sauvé L, Gingras S, Ayotte P, Holub BJ. n-3 fatty acids and cardiovascular disease risk factors among the Inuit of Nunavik. Am J Clin Nutr 2001;74:464-73.

14. Kuhnlein HV, Chan HM, Leggee D, Barthet V. Macronutrient, mineral and fatty acid composition of Canadian Arctic traditional food. J Food Comp Anal 2002;15:545-66.

15. Bersamin A, Luick BR, Ruppert E, Stern JS, ZidenbergCherr S. Diet quality among Yup'ik Eskimos living in rural communities is low: the Center for Alaska Native Health Research Pilot Study. J Am Diet Assoc 2006;106:1055-63.

16. Nobmann ED, Ponce R, Mattil C, Devereux R, Dyke $\mathrm{B}$, Ebbesson SO et al. Dietary intakes vary with age among Eskimo adults of Northwest Alaska in the GOCADAN study, 2000-2003. J Nutr 2005;135:856-62.

17. Lebrun JB, Moffatt ME, Mundy RJ, Sangster RK, Postl $\mathrm{BD}$, Dooley JP et al. Vitamin D deficiency in a Manitoba community. Can J Public Health 1993;84:394-6.
18. Kuhnlein HV, Receveur O. Dietary change and traditional food systems of indigenous peoples. Annu Rev Nutr 1996;16:417-42.

19. Kuhnlein HV, Receveur O, Soueida R, Berti PR. Unique patterns of dietary adequacy in three cultures of Canadian Arctic indigenous peoples. Public Health Nutr 2008;11:349-60.

20. Public Health Agency of Canada. Surveillance Division. Centre for Chronic Disease Prevention and Control. Canada: Surveillance Division, Public Health Agency of Canada, 2008. 3 p. (http://www.phac-aspc. gc.ca/ccdpc-cpcmc/about_e.html, accessed on 28 March 2010).

21. Hopping BN, Erber E, Mead E, Roache C, Sharma S. High levels of physical activity and obesity co-exist amongst Inuit adults in Arctic Canada. J Hum Nutr Diet 2010;23:110-4.

22. Hopping BN, Mead E, Erber E, Sheehy C, Roache C, Sharma S. Dietary adequacy of Inuit in the Canadian Arctic. J Hum Nutr Diet 2010;23:27-34.

23. Sharma S, Cao X, Roache C, Buchan A, Reid R, Gittelsohn J. Assessing dietary intake in a population undergoing a rapid transition in diet and lifestyle: the Arctic Inuit in Nunavut, Canada. Br J Nutr 2010; 103:749-59.

24. Stothard KJ, Tennant PWG, Bell R, Rankin J. Maternal overweight and obesity and the risk of congenital anomalies: a systematic review and meta-analysis. $J$ Am Med Assoc 2009;301:636-50.

25. Hornberger LK. Maternal diabetes and the fetal heart. Heart 2006;92:1019-21.

26. Loeken MR. Advances in understanding the molecular causes of diabetes-induced birth defects. Reprod Sci 2006;13:2-10.

27. American College of Obstetricians and Gynecologists. Pregestational diabetes mellitus. ACOG Pract Bull Obstet Gynecol 2005;105:675-85.

28. Correa A, Gilboa SM, Besser LM, Botto LD, Moore CA, Hobbs CA et al. Diabetes mellitus and birth defects. Am J Obstet Gynecol 2008;199:e1-9.

29. Arbour L, Gilpin C, Millor-Roy V, Platt R, Pekeles G, Egeland GM et al. Heart defects and other malformations in the Inuit in Canada: a baseline study. Int J Circumpolar Health 2004;63:251-66.

30. Zaadstra BM, Seidell JC, Van Noord PA, te Velde ER, Habbema JD, Vrieswijk B et al. Fat and female fecundity: prospective study of effect of body fat distribution on conception rates. Br Med J 1993;306:484-7.

31. Catalano PM. Management of obesity in pregnancy. Obstet Gynecol 2007;109:419-33.

32. Torloni MR, Betrán AP, Horta BL, Nakamura MU, Atallah AN, Moron AF et al. Prepregnancy BMI and the risk of gestational diabetes: a systematic review of the litera- 
ture with meta-analysis. Obes Rev 2009;10:194-203.

33. Yeung EH, Hu FB, Solomon CG, Chen L, Louis GM, Schisterman E et al. Life-course weight characteristics and the risk of gestational diabetes. Diabetologia 2010;53:668-78.

34. Nohr EA, Timpson NJ, Andersen CS, Davey Smith G, Olsen J, Sørensen TI. Severe obesity in young women and reproductive health: the Danish National Birth Cohort. PLoS One 2009; 4:e8444.

35. Ray JG, Wyatt PR, Vermeulen MJ, Meier C, Cole DE. Greater maternal weight and the ongoing risk of neural tube defects after folic acid flour fortification. $\mathrm{Ob}$ stet Gynecol 2005;105:261-5.

36. Daly LE, Kirke PN, Molloy A, Weir DG, Scott JM. Folate levels and neural tube defects: implications for prevention. J Am Med Assoc 1995;274:1698-702.

37. World Health Organization. Vitamin and mineral requirements in human nutrition. Report of a Joint FAO/WHO Expert Consultation, Bangkok, Thailand. 2nd ed. Geneva: World Health Organization, 2004. $340 \mathrm{p}$.

38. Sinning AR. Role of vitamin A in the formation of congenital heart defects. Anat Rec 1998;253:147-53.

39. Christian P, Stewart CP. Maternal micronutrient deficiency, fetal development, and the risk of chronic disease. J Nutr 2010;140:437-45.

40. Godfrey KM, Gluckman PD, Hanson MA. Developmental origins of metabolic disease: life course and intergenerational perspectives. Trends Endocrinol Metab 2010;21:199-205.

41. Fall C. Maternal nutrition: effects on health in the next generation. Indian J Med Res 2009;130:593-9.

42. Statistics Canada. 2006 aboriginal population profile.(http://www12.statcan.gc.ca/censusrecensement/2006/dp-pd/prof/92-594/index. cfm?Lang=E, accessed on 7 April 2010).

43. Library and Archives Canada. Map of Nunavut. (http://www.lac-bac.gc.ca/inuit/020018-1601-e.html, accessed on 20 December 2010).

44. Sharma S. Assessing diet and lifestyle in the Canadian Arctic Inuit and Inuvialuit to inform a nutrition and physical activity intervention programme. J Hum Nutr Diet 2010;23:5-17.

45. Indian and Northern Affairs Canada. Regional results of price surveys. Kitikmeot Region, Nunavut: Indian and Northern Affairs Canada, 2008. 26 p. (http:// www.ainc-inac.gc.ca/nth/fon/fc/rgrs-eng.asp\#ntr, accessed on 11 April 2010).

46. Pakseresht M, Sharma S. Validation of a quantitative food frequency questionnaire for Inuit population in Nunavut, Canada. J Hum Nutr Diet 2010;23:67-74.

47. Institute of Medicine of the National Academies.
Dietary reference intakes for energy, carbohydrates, fiber, fat, fatty acids, cholesterol, protein and amino acids. Washington, DC: National Academies Press, 2005. $1357 \mathrm{p}$.

48. World Health Organization. Global database on body mass index; BMI classification. Geneva: World Health Organization, 2005. 2 p. (http://apps.who. int/bmi/index.jsp?introPage=intro_3.html, accessed on 6 April 2010).

49. Berghella V, Buchanan E, Pereira L, Baxter JK. Preconception care. Obstet Gynecol Surv 2010;65:119-31.

50. Chmurzynska A. Fetal programming: link between early nutrition, DNA methylation, and complex diseases. Nutr Res 2010;68:87-98.

51. Fleming TP, Kwong WY, Porter R, Ursell E, Fesenko I, Wilkins A et al. The embryo and its future. Biol Reprod 2004;71:1046-54.

52. Ravelli AC, van Der Meulen JH, Osmond C, Barker, DJ, Blekern OP. Obesity at the age of $50 \mathrm{y}$ in men and women exposed to famine prenatally. Am J Clin Nutr 1999;70:811-6.

53. Boney CM, Verma A, Tucker R, Vohr BR. Metabolic syndrome in childhood: association with birth weight, maternal obesity, and gestational diabetes mellitus. Pediatrics 2005;115:290-6.

54. Silverman BL, Rizzo TA, Cho NH, Metzger BE. Longterm effects of the intrauterine environment. The Northwestern University Diabetes in Pregnancy Center. Diabetes Care 1998;21:B142-9.

55. Mulligan ML, Felton SK, Riek AE, Bernal-Mizrachi C. Implications of vitamin D deficiency in pregnancy and lactation. Am J Obstet Gynecol 2010;202:429.e1-9.

56. Viljakainen HT, Saarnio E, Hytinantti T, Miettinen M, Surcel H, Mäkitie O et al. Maternal vitamin D status determines bone variables in the newborn. J Clin Endocrinol Metab 2010;95:1749-57.

57. Soheilykhah S, Mojibian M, Rashidi M, Rahimi-Saghand S, Jafari F. Maternal vitamin D status in gestational diabetes mellitus. Nutr Clin Pract 2010;25:524-7.

58. Huotari A, Herzig KH. Vitamin D and living in northern latitudes-an endemic risk area for vitamin D deficiency. Int J Circumpolar Health 2008;67:164-78.

59. Jenkins AL, Gyorkos TW, Culman KN, Ward BJ, Pekeles GS, Mills EL. An overview of factors influencing the health of Canadian Inuit infants. Int J Circumpolar Health 2003;62:17-39.

60. De Wals P, Van Allen MI, Lowry RB, Evans JA, Van den Hof MC, Crowley $\mathrm{M}$ et al. Impact of folic acid food fortification on the birth prevalence of lipomyelomeningocele in Canada. Birth Defects Res A Clin Mol Teratol 2008;82:106-9.

61. Godel JC, Basu TK, Pabst HF, Hodges RS, Hodges PE, $\mathrm{Ng}$ ML. Perinatal vitamin A (retinol) status of north- 
ern Canadian mothers and their infants. Biol Neonate 1996;69:133-9.

62. Dallaire F, Dewailly E, Shademani R, Laliberté C, Bruneau S, Rhainds $\mathrm{M}$ et al. Vitamin A concentration in umbilical cord blood of infants from three separate regions of the province of Québec (Canada). Can J Public Health 2003;94:386-90.

63. Leslie WD, Weiler HA, Nyomba BL. Ethnic differences in adiposity and body composition: the First Nations bone health study. Appl Physiol Nutr Metab
2007;32:1065-72.

64. U.S. Department of Health and Human Services. The Surgeon General's call to action to prevent and decrease overweight and obesity. Rockville, MD: Office of the Surgeon General, U.S. Public Health Service, 2001. 60 p.

65. Ludwig DS. The glycemic index; physiological mechanisms relating to obesity, diabetes, and cardiovascular disease. JAMA 2002;287:2414-23. 